\title{
Psychopathology
}

\section{No. 1}

Original Papers

1 A Structure-Based Expert Model of the ICD-10 Mental Disorders

Egli, S.; Schlatter, K.; Streule, R.; Läge, D. (Zürich)

10 Why Do People Injure Themselves? Haas, B.; Popp, F. (Salzburg)

19 Impact of Temperamental Mood Lability on Depressive Mixed State

Benazzi, F. (Ravenna)

25 Biogenetic Temperament and Character and Attention Deficit Hyperactivity Disorder in Korean Children

Yoo, H.J. (Jinju); Kim, M. (Seoul); Ha, J.H. (Yongin); Chung, A.; Sim, M.E. (Seoul); Kim, S.J. (Incheon); Lyoo, I.K. (Seoul)

49 Childhood Inattention and Hyperactivity Symptoms Self-Reported by Adults with Asperger Syndrome Tani, P.; Lindberg, N.; Appelberg, B.; Nieminen-von Wendt, T.; von Wendt, L.; Porkka-Heiskanen, T. (Helsinki)

\section{Case Reports}

32 Investigation of the Syndrome of Apotemnophilia and Course of a Cognitive-Behavioural Therapy

Braam, A.W.; Visser, S.; Cath, D.C.; Hoogendijk, W.J.G. (Amsterdam)

38 Vocalisation in Verbal Hallucinations: Case Report and Theoretical Model Behrendt, R.-P.; Whittingham, M. (Chesterfield)

45 Delusions or Obsessions: The Same Only Different? A Case Report

Sanders, J.; Whitty, P.; Murray, D.; Devitt, P. (Dublin)

\section{No. 2}

Review

55 Aggressiveness, Anger and Eating Disorders: A Review Truglia, E.; Mannucci, E.; Lassi, S.; Rotella, C.M.; Faravelli, C.; Ricca, V. (Florence)

Original Papers

69 Seasonal Variation of Sexual Abuse in Santiago de Chile Téllez, C.; Galleguillos, T.; Aliaga, A.; Silva, C. (Santiago)

75 Seasonal Variation in Suicidal Deaths in Chile: Its Relationship to Latitude Heerlein, A.; Valeria, C.; Medina, B. (Santiago de Chile)

80 The Relationship between the Biogenetic Temperament and Character and Psychopathology in Adolescents

Kim, S.J. (Incheon); Lee, S.J.; Yune, S.K.; Sung, Y.H.; Bae, S.C.; Chung, A.; Kim, J.; Lyoo, I.K. (Seoul)

87 'Mind Control' Experiences on the Internet: Implications for the Psychiatric Diagnosis of Delusions

Bell, V.; Maiden, C. (Cardiff); Muñoz-Solomando, A. (Swansea); Reddy, V. (Cardiff)

92 Analysis of Delusional Statements from 15 Japanese Cases of 'Folie à Deux'

Shimizu, M. (Kobe); Kubota, Y. (Shiga-ken); Calabrese, J.R.

(Cleveland, Ohio); Toichi, M. (Kyoto); Kato, S. (Tochigi-ken); Baba, H. (Kobe)

Case Report

99 Shared Obsessive-Compulsive Disorder Grover, S.; Gupta, N. (Chandigarh)

Letter to the Editor

102 Inverse Correlation between Severity of Psychopathic Traits and Serum Cortisol Levels in Young Adult Violent Male Offenders

Holi, M.; Auvinen-Lintunen, L.; Lindberg, N.; Tani, P.; Virkkunen, M. (Helsinki)

101 Erratum

\section{KARGER}

Fax +41613061234 E-Mail karger@karger.ch www.karger.com

\section{(C) 2006 S. Karger AG, Basel}

Access to full text and tables of contents, including tentative ones for forthcoming issues: www.karger.com/psp_issues 
No. 3

Original Papers

105 Psychosocial Factors Associated with Knowledge about Affective Disorders in Patients with Depression Kronmüller, K.-T.; Saha, R.; Karr, M.; Kratz, B.; Hunt, A.; Mundt, C.; Backenstrass, M. (Heidelberg)

113 Prevalence of Typus Melancholicus in Healthy Germans Ueki, H. (Gifu); Holzapfel, C. (Münster); Sakado, K. (Niigata); Washino, K.; Inoue, M.; Ogawa, N. (Gifu); Ietsugu, T. (Inuyama); Takai, A. (Seki)

120 Persistent Auditory Hallucinations González, J.C.; Aguilar, E.J.; Berenguer, V.; Leal, C.; Sanjuan, J. (Valencia)

126 Wittgenstein's Philosophy and a Dimensional Approach to the Classification of Mental Disorders - A Preliminary Scheme Mackinejad, K.; Sharifi, V. (Tehran)

130 Body Dysmorphic Disorder, Psychosis and Insight: A Report of Four Cases

Lucchelli, J.P.; Bondolfi, G.; Bertschy, G. (Geneva)

136 Measuring Adult Attachment Representation in an fMRI Environment: Concepts and Assessment

Buchheim, A. (Ulm); George, C. (Oakland, Calif.); Kächele, H.; Erk, S.; Walter, H. (Ulm)

144 Measuring Attachment Representation in an fMRI Environment: A Pilot Study

Buchheim, A.; Erk, S. (Ulm); George, C. (Oakland, Calif.); Kächele, H. Ruchsow, M.; Spitzer, M. (Ulm); Kircher, T. (Aachen); Walter, H. (Ulm)

153 Eating Disorders and Attitudes in Maltese and Italian Female Students

Santonastaso, P.; Scicluna, D.; Colombo, G.; Zanetti, T.; Favaro, A. (Padua)

Letter to the Editor

158 Early Withdrawal in a Double-Blind Randomized Clinical Trial with Olanzapine and Risperidone Performed in Adolescents with First Psychosis

van Nimwegen, L.; de Haan, L. (Amsterdam)

No. 4

Original Papers

159 Posttraumatic Syndromes in Children and Adolescents after Road Traffic Accidents - A Prospective Cohort Study Schäfer, I.; Barkmann, C.; Riedesser, P.; Schulte-Markwort, M. (Hamburg)

165 Parental Attachment and Its Impact on the Development of Psychiatric Manifestations in School-Aged Children Yoo, H.I.; Kim, B.-N.; Shin, M.S.; Cho, S.C.; Hong, K.-E. (Seoul)

175 Cannabis-Induced Psychotic-Like Experiences Are Associated with High Schizotypy

Barkus, E.J.; Stirling, J.; Hopkins, R.S.; Lewis, S. (Manchester)

179 Assessing the Social Behavior of Unipolar Depressives: The Criteria for Typus melancholicus Stanghellini, G.; Bertelli, M. (Florence)

187 Full and Partial Post-Traumatic Stress Disorder among World War II Prisoners of War

Favaro, A.; Tenconi, E.; Colombo, G.; Santonastaso, P. (Padova)

192 Narcissistic Regulation of the Self and Interpersonal Problems in Depersonalized Patients

Michal, M.; Kaufhold, J.; Overbeck, G.; Grabhorn, R. (Frankfurt am Main)

199 Auditory Recognition Memory, Conscious Recollection, and Executive Function in Patients with Schizophrenia Drakeford, J.L. (Birmingham); Edelstyn, N.M. (Keele); Oyebode, F.; Srivastava, S.; Calthorpe, W.R.; Mukherjee, T. (Birmingham)
No. 5

Original Papers

209 Towards an Empirically Based Validation of Intuitive Diagnostic: Rümke's 'Praecox Feeling' across the Schizophrenia Spectrum: Preliminary Results Grube, M. (Frankfurt a.M.)

218 Associations between Delusion Proneness and Personality Structure in Non-Clinical Participants: Comparison between Young and Elderly Samples

Larøi, F. (Liège); Van der Linden, M. (Liège/Geneva); DeFruyt, F. (Ghent); van Os, J. (Maastricht/London); Aleman, A. (Groningen)

227 Predictors of Attention Problems for the Period from Pre-Teen to Early Teen Years

Barnow, S. (Stralsund); Schuckit, M.; Smith, T. (San Diego, Calif.); Freyberger, H.J. (Stralsund)

236 The Role of Trauma and PTSD-Related Symptoms for Dissociation and Psychopathological Distress in Inpatients with Schizophrenia Vogel, M.; Spitzer, C.; Barnow, S.; Freyberger, H.J.; Grabe, H.J. (Greifswald)

243 Path Analytical Study of the Short Version of the WHO Quality of Life Instrument

Ohaeri, J.U. (Ibadan); Olusina, A.K. (Newton-le-Willows); Al-Abassi, A.-H.M. (Safat)

248 Clinical Correlates of Self-Mutilation in Turkish Male Substance-Dependent Inpatients Evren, C.; Kural, S.; Cakmak, D. (Istanbul)

255 Denial of Symptoms and Psychopathology in Adolescent Anorexia Nervosa

Viglione, V.; Muratori, F.; Maestro, S.; Brunori, E.; Picchi, L. (Pisa)

No. 6

Original Papers

261 Approaching Delusional Misidentification Syndromes as a Disorder of the Sense of Uniqueness

Margariti, M.M.; Kontaxakis, V.P. (Athens)

269 Diagnostic Agreement of Schizophrenia Spectrum Disorders among Chronic Patients with Functional Psychoses Jakobsen, K.D. (Roskilde); Frederiksen, J.N.; Parnas, J. (Broendby); Werge, T. (Roskilde)

277 Interpretation of Ambiguous Idiomatic Statements in Schizophrenic and Depressive Patients. Evidence for Common and Differential Cognitive Patterns

Iakimova, G. (Le Chesnay/Saint-Denis); Passerieux, C.; Hardy-Baylé, M.-C. (Le Chesnay)

286 Characterization of Patients with Schizophrenia and Related Psychoses: Evaluation of Different Diagnostic Procedures Vares, M.; Ekholm, A.; Sedvall, G.C.; Hall, H.; Jönsson, E.G. (Stockholm)

296 Delusional Misidentification Syndrome: Why Such Nosologic Challenge Remains Intractable

Rodrigues, A.C.T.; Banzato, C.E.M. (Campinas)

303 A Qualitative Examination of the Experience of 'Depression' in Hospitalized Medically III Patients

Clarke, D.M.; Cook, K.E.; Coleman, K.J.; Smith, G.C. (Melbourne)

313 Author Index Vol. 39, 2006

314 Subject Index Vol. 39, 2006 